\title{
PROFESOR ROMUALD BOGOCZEK (1930-2014) - WSPOMNIENIE 30 LAT PRACY NA WYDZIALE INŻYNIERYJNO-EKONOMICZNYM
}

DOI: $10.15611 /$ nit.2015.1.01

Trzynastego listopada 2014 r. zmarł prof. $d r$ hab. inż. Romuald Bogoczek - Honorowy Profesor Akademii Ekonomicznej we Wrocławiu, założyciel Katedry Technologii Chemicznej na Wydziale Inżynieryjno-Ekonomicznym i do 2003 r. jej kierownik.

Pan Profesor Romuald Bogoczek urodził się 4 maja 1930 r. w Chorzowie. W 1956 r. ukończył studia na Wydziale Chemicznym Politechniki Śląskiej w Gliwicach, a w okresie 1958-1975 pracował na tym wydziale jako nauczyciel akademicki. Tam też w 1963 r. obronił pracę doktorską pt. Badania i rozdziat produktów utleniania

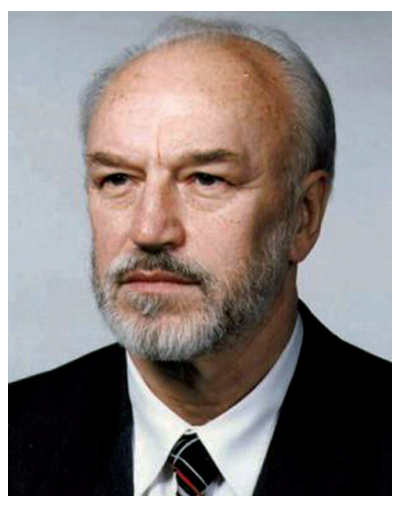
węglowodanów i uzyskał stopień naukowy doktora nauk technicznych. Promotorem Jego pracy doktorskiej była prof. dr inż. Czesława Troszkiewicz. W 1970 r. został doktorem habilitowanym nauk chemicznych w zakresie chemii organicznej. Temat Jego rozprawy habilitacyjnej brzmiał następująco: Studia nad synteza kwasu L-askorbinowego z L-sorbozy.

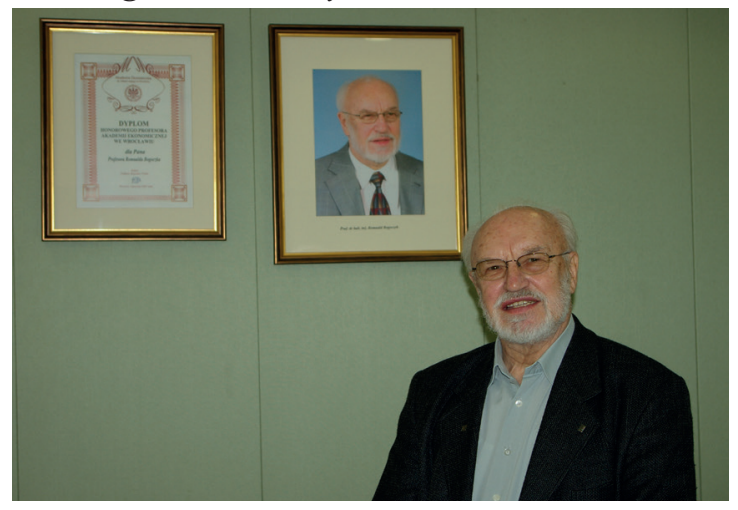

W 1975 r. Profesor Bogoczek wygrał konkurs na kierownika Zakładu Technologii Przemysłu Chemicznego na Wydziale Inżynieryjno-Ekonomicznym Przemysłu Akademii Ekonomicznej we Wrocławiu i przeniósł się z Gliwic do Wrocławia. Zorganizował pracę tej nowej jednostki od podstaw i kierował nią do 2003 r. Pan Profesor, reprezentujący nauki techniczne, był 
jedną z osób, dzięki którym na Wydziale Inżynieryjno-Ekonomicznym mógł być realizowany interdyscyplinarny profil kształcenia studentów, łączący wiedzę z dziedzin inżynierskich z wiedzą ekonomiczną i menedżerską. W latach 1981-1984 i 1988-1990 pełnił funkcję prodziekana, a w latach 1990-1993 dziekana Wydziału Inżynieryjno-Ekonomicznego (na fotografii obok Pan Profesor w sali Rady Wydziału na tle swojego zdjęcia). W roku 1994 przyznano Mu tytuł profesora nauk technicznych.

Profesor Romuald Bogoczek wypromował ośmiu doktorów nauk technicznych. Wśród doktorantów Pana Profesora, oprócz pracowników naukowo-dydaktycznych katedry, były również osoby spoza Uczelni (dr inż. Paweł Nowak i dr inż. Julia Tomaszewska). Jedna z doktorantek Profesora, dr inż. Joanna Surowiec, przez kilkanaście lat pracowała w zagranicznych koncernach chemicznych (National Chemical Products w RPA, Rohm and Haas Company we Francji), weryfikując i poszerzając wiedzę zdobytą w Katedrze Technologii Chemicznej.

Pan Profesor Romuald Bogoczek pozostawił dorobek naukowy, na który składają się artykuły opublikowane $w$ takich czasopismach o zasięgu międzynarodowym, jak: "Polymer", "Polymer Communications", Reactive \& Functional Polymers", "Journal of Applied Polymer Science", "Industrial \& Engineering Chemistry Research", "Pure and Applied Chemistry", "Catalysis Today", "Photochemical and Photobiological Sciences", "Journal of Thermal Analysis", "Journal of Chromatography", "Die Angewandte Makromolekulare Chemie", "Chemie Ingenieur Technik". Czasopisma te pochodzą z prestiżowych wydawnictw naukowych, takich jak Elsevier, Wiley, Royal Society of Chemistry, ACS Publications.

Duże znaczenie w pracy naukowej Pana Profesora miały popularyzacja i synteza wiedzy, o czym świadczą liczne artykuły przeglądowe, opublikowane w krajowych, centralnych czasopismach (zwłaszcza w miesięczniku „Przemysł Chemiczny”), przybliżające tematykę polimerów reaktywnych jako materiałów przydatnych w wielu obszarach technologii chemicznej i ochrony środowiska. Artykuły autorstwa Pana Profesora cytowane były prawie 300 razy, co świadczy o Jego wysokiej pozycji w środowisku naukowym. Najczęściej cytowaną pracą Profesora (53 cytowania) jest artykuł pt. Studies on the thermal stability of the perfluorinated cation-exchange membrane Nafion-417, który ukazał się w 1988 r. w czasopiśmie „Journal of Thermal Analysis”.

Wyrazem uznania przez społeczność naukową dla osiągnięć w dziedzinie syntezy, badania właściwości oraz zastosowań polimerów reaktywnych było powierzenie Profesorowi Bogoczkowi i Katedrze Technologii Chemicznej przez Międzynarodowy Komitet Doradczy, wywodzący się z kręgu czasopisma "Reactive \& Functional Polymers", organizacji konferencji naukowej 7th International Conference on Polymer Supported Reaction in Organic Chemistry POC'96. Konferencja ta odbyła się 24-28 czerwca 1996 r. na terenie Akademii Ekonomicznej

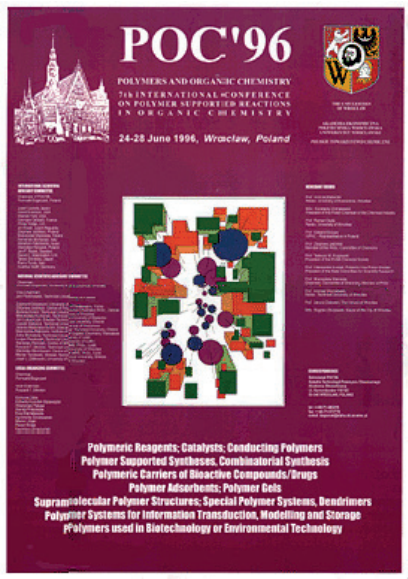


we Wrocławiu. Uczestniczyli w niej naukowcy z 25 krajów, z czterech kontynentów. Konferencja była dużym osiągnięciem naukowym i organizacyjnym. Materiały konferencyjne, będące jej efektem, to: Scientific Program, List of Authors of Papers, a także monografia stanowiąca zbiór streszczeń - Abstracts of Lectures and Oral \& Poster Contributions, POC'96 (Publishing House of the Oscar Lange University of Economics in Wrocław, Wrocław 1996, 384 strony, ISBN 83-7011-225-0).

Stale obecna w działalności naukowo-badawczej i dydaktycznej Katedry Technologii Chemicznej, szeroko rozumiana problematyka ochrony środowiska zaowocowała

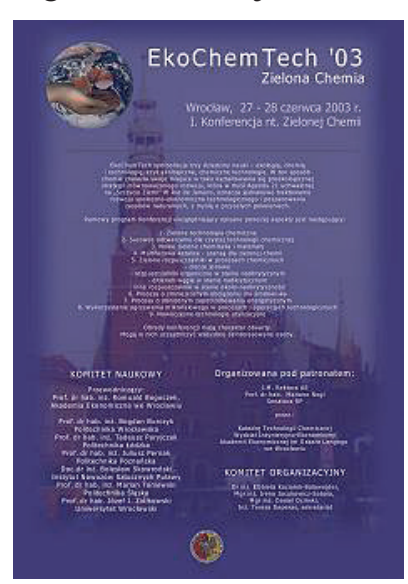
zorganizowaniem pod kierunkiem naukowym Profesora Romualda Bogoczka pierwszej w Polsce konferencji naukowej dotyczącej zielonej chemii: EkoChemTech'03. Konferencja ta odbyła się 27-28 czerwca 2003 r. w naszej Uczelni. Uczestniczyło w niej ok. 150 osób, m.in. z Niemiec, ze Szwajcarii, z Ukrainy i Rumunii. Wystąpienia miały charakter referatów i posterów. Materiały konferencyjne, będące jej efektem, to: Harmonogram konferencji, Zbiór streszczeń (109 stron) oraz monografia zawierająca zbiór artykułów, nosząca tytuł Zielona chemia, opublikowana pod redakcją naukową Romualda Bogoczka (Prace Naukowe Akademii Ekonomicznej we Wrocławiu nr 1041, Wrocław 2004, 225 stron, PL ISSN 0324-8445).

Pan Profesor brał udział w organizowaniu kolejnych konferencji z cyklu POC, które odbyły się w 1998 r. w Jerozolimie, w 2000 r. - w Tianjin, w 2002 r. - w San Diego i w 2004 r. - w Pradze. Był też zaangażowany w organizację pierwszych Kongresów Technologii Chemicznej, stanowiących najważniejsze krajowe konferencje w tym obszarze. Był aktywnym członkiem Komitetu Naukowego kolejnych konferencji w Szczecinie (1994 r.), we Wrocławiu (1997 r.), w Gliwicach (w 2000 r.) i Łodzi (2003 r.), a także aktywnie uczestniczył w wielu naukowych konferencjach krajowych i zagranicznych.

Pan Profesor Romuald Bogoczek współpracował z praktyką przemysłową, wykonując na jej rzecz różnorodne badania i ekspertyzy - m.in. wytwarzanie, na podstawie wcześniej opracowanych własnych technologii w ramach produkcji antyimportowej, związków organicznych, takich jak: kwas hydroksyetylidenodifosfonowy, kwas 2,4-dinitrobenzoesowy, $N$-etylomaleinimid, fosforan tri-n-butylu, oraz związków chemicznych o wysokiej czystości: kwasu 3,4,5-trihydroksybenzoesowego i aldehydu 3,4,5-trimetoksybenzoesowego. Kolejne duże przedsięwzięcie badawcze Profesora, realizowane przez Niego kilka lat, było związane z wyodrębnianiem tiocyjanianu sodu i innych związków siarki z roztworów technologicznych różnego pochodzenia, m.in. z instalacji wytwarzania akrylonitrylu (w 1988 r. otrzymał Nagrodę Zespołową Ministra Edukacji Narodowej z tytułu osiągnięć naukowych i postępu naukowo-technicznego), z instalacji oczyszczania gazu koksowniczego z różnych hut, a także z obiegowych roztworów pochodzących z produkcji poliakrylonitrylu. Ciekawe 
zagadnienie badawcze dotyczyło oczyszczania roztworów kwasu mlekowego oraz ich analizy za pomocą HPLC. Istotnym składnikiem dorobku Pana Profesora są liczne patenty (krajowe i zagraniczne), będące efektem zarówno współpracy z praktyką przemysłową, jak i badań naukowych prowadzonych w Katedrze.

Z inicjatywy Pana Profesora Romualda Bogoczka na naszym Wydziale utworzono w latach 90. nową specjalność - inżynierię ochrony środowiska. Pan Profesor na Wydziale Inżynieryjno-Ekonomicznym prowadził wykłady z różnych przedmiotów, dla studentów studiów stacjonarnych i niestacjonarnych dwóch specjalności, tzw. chemicznej i środowiskowej. Były to m.in.: technologia chemiczna organiczna, wybrane zagadnienia $\mathrm{z}$ technologii chemicznej, projektowanie technologiczne, chemia środowiska, seminarium magisterskie.

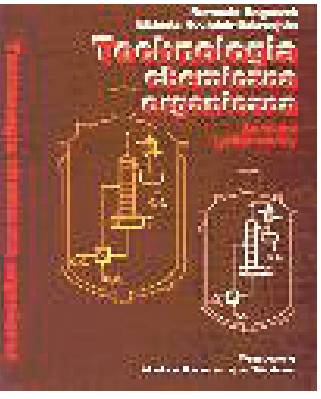
Profesor Bogoczek jest współautorem znanego i cenionego podręcznika akademickiego pt. Technologia chemiczna organiczna - surowce i pótprodukty oraz kilku skryptów, które były wykorzystywane przez społeczność akademicką na terenie całego kraju.

W okresie aktywności zawodowej Pan Profesor Romuald Bogoczek był wielokrotnie nagradzany. Otrzymał też liczne odznaczenia, m.in. Medal Komisji Edukacji Narodowej i Krzyż Kawalerski Orderu Odrodzenia Polski. W 2006 r. Pan Profesor przeszedł na emeryturę, ale przez następne lata dalej aktywnie uczestniczył w życiu naukowym Katedry. Szóstego grudnia 2007 r. w auli naszej Uczelni odbyła się uroczysta akademia, podczas której przyznano Panu Profesorowi tytuł Honorowego Profesora Akademii Ekonomicznej we Wrocławiu - najwyższe wyróżnienie nadawane przez Rektora i Senat osobom najbardziej zasłużonym dla rozwoju naszego. Dyplom wręczył Rektor Akademii Ekonomicznej we Wrocławiu prof. dr hab. Bogusław Fiedor (poniżej zdjęcia z tej uroczystości).
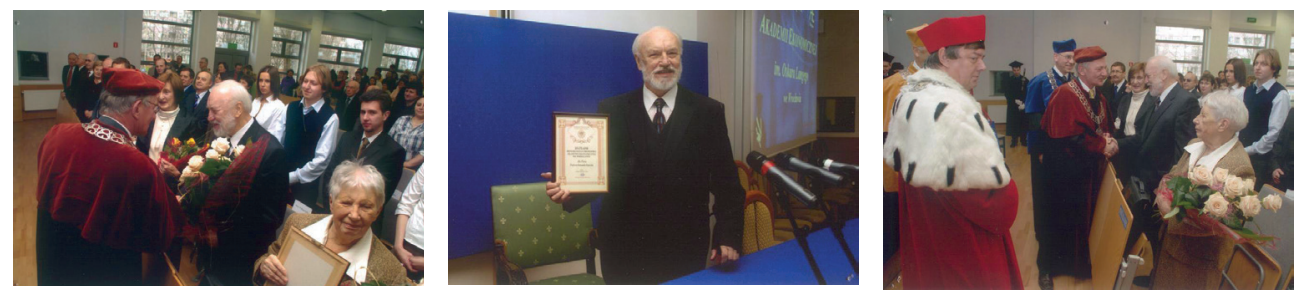

Pan Profesor Romuald Bogoczek pochowany został na cmentarzu parafialnym kościoła św. Jadwigi w Chorzowie. Pozostanie w pamięci współpracowników jako wybitny naukowiec, założyciel i twórca naszej Katedry, nasz nauczyciel i wychowawca, a także człowiek bardzo nam bliski i życzliwy. Dorobek naukowy Profesora Romualda Bogoczka jest trwałym i istotnym składnikiem dorobku polskiej nauki. 


\section{Dorobek naukowy i dydaktyczny Prof. dr. hab. inż. Romualda Bogoczka od 1975 r. (z okresu zatrudnienia na naszej Uczelni)}

\section{Artykuły}

Bogoczek R., Badania nad zapobieganiem wytracaniu się osadów w technicznym ekstrakcyjnym kwasie fosforowym, przez zastosowanie wymieniaczy jonowych lub sekwestrantów, Prace Naukowe Akademii Ekonomicznej we Wrocławiu, Chemia, 1976, 91, 205-211.

Bogoczek R., Surowiec J., Żychiewicz A., Kłys H., Cisowski R., Zastosowanie PCl3 i H3PO3 do syntezy kompleksonów, Prace Naukowe Akademii Ekonomicznej we Wrocławiu, Chemia, 1976, 91, 213-218.

Bogoczek R., Pałka Z., Wieczorek M., Otrzymywanie kwasu winowego z jego trudno rozpuszczalnych soli z zastosowaniem jonitów na drodze niejonowymiennej, Prace Naukowe Akademii Ekonomicznej we Wrocławiu, Technologia, 1977, 118, 141-163.

Bogoczek R., Swoboda A., Ilościowe oznaczanie glikolu etylenowego i kwasu szczawiowego w mieszaninach tych składników z kwasem azotowym, Prace Naukowe Akademii Ekonomicznej we Wrocławiu, Technologia, 1977,100, 127-145.

Bogoczek R., Nowe złożone jonity typu Snake-Cage i Net-Cage o polikondensacyjnym składniku liniowym, Prace Naukowe Akademii Ekonomicznej we Wrocławiu, Technologia, 1978, 140, 123-146.

Bogoczek R., Kłys H., Badanie zdolności sekwestrujacej kwasu fosforowego i jego pochodnych, Prace Naukowe Akademii Ekonomicznej we Wrocławiu, Chemia, 1978, 132, 249-259.

Bogoczek R., Kłys H., Badanie zdolności sekwestrujacej wybranych kompleksonów wobec jonów metali w zależności od $p H$, „Przemysł Chemiczny”, 1978, 57, 423-425.

Bogoczek R., Kociołek E., Miemus G., Badania nad utylizacją ścieków fosforanowych do produkcji fosforanów sodu i potasu przy zastosowaniu techniki jonitowej, Prace Naukowe Akademii Ekonomicznej we Wrocławiu, Chemia, 1978, 132, 265-276.

Bogoczek R., Surowiec J., Badania nad oczyszczaniem ekstrakcyjnego kwasu fosforowego za pomoca wymieniaczy jonowych, Prace Naukowe Akademii Ekonomicznej we Wrocławiu, Chemia, 1978, 132, 261-263.

Bogoczek R., Surowiec J., Obecny stan rozwoju wymieniaczy jonowych, „Przemysł Chemiczny”, 1978, 57, 51-56.

Bogoczek R., Surowiec J., Procesy jonitowe w technologii chemicznej, „Przemysł Chemiczny”, 1978, 57, 217-221.

Bogoczek R., Surowiec J., Zając K., Badania nad wyodrębnianiem grup składników ze smoły koksowniczej i z oleju karbolowego za pomoca wymieniaczy jonowych, „Koks, Smoła, Gaz”, 1978, 23, 176-179.

Bogoczek R., Zielińska Z., Oznaczanie grup funkcyjnych wystepujacych w amfoterycznych wymieniaczach jonowych typu Snake-Cage i Net-Cage, „Przemysł Chemiczny”, 1978, 57, 357-360.

Bogoczek R., Kociołek E., Redoksyty sulfhydrylowe - cenne materiały pomocnicze w technologii chemicznej, „Przemysł Chemiczny”, 1979, 58, 273-276.

Bogoczek R., Kuszka W., Nowak P., Wybór optymalnej metody produkcji kwasu szczawiowego dla ZA Chorzów, „Przemysł Chemiczny”, 1979, 58, 74-76.

Bogoczek R., Surowiec J., Markowska-Nieznalska A., Badania nad oczyszczaniem surowej gliceryny mydlarskiej za pomoca różnych procesów jonitowych, „Przemysł Chemiczny”, 1979, 58, 433-436.

Bogoczek R., Badania nad rozdziałem melasu cukrowego na grupy składników za pomoca procesów jonitowych, Prace Naukowe Akademii Ekonomicznej we Wrocławiu, Technologia, 1980, 167, 155-175.

Bogoczek R., Konopka J., Jonity ciekte w technologii chemicznej, „Przemysł Chemiczny”, 1980, 59, 588-590. 
Bogoczek R., Miemus G., Chromatografia jonowa - jeszcze jedna analityczna technika jonitowa, „Przemysł Chemiczny”, 1980, 59, 471-474.

Bogoczek R., Surowiec J., Synthesis of phosphorus-containing Wofatit cation exchangers and their affinity toward selected cations, "Journal of Applied Polymer Science", 1981, 26, 4161-4173.

Bogoczek R., Statyka reakcji sulfonowania związków aromatycznych określona pojęciem

$\pi$-sulfonowania wskazująca na stopień podatności pierścienia aromatycznego na reakcje substytucji elektrofilowej (SE), Prace Naukowe Akademii Ekonomicznej we Wrocławiu, Technologia, 1982, 191, 163-173.

Bogoczek R., Kociołek-Balawejder E., Otrzymywanie czystego kwasu 2,4-dinitro-benzoesowego z technicznego dinitrotoluenu, „Przemysł Chemiczny”, 1982, 61, 383-386.

Bogoczek R., Kociołek-Balawejder E., Miemus G., Otrzymywanie aldehydu anyżowego z p-nitrotoluenu z zastosowaniem środowiska niewodnego dla reakcji metylowania, Prace Naukowe Akademii Ekonomicznej we Wrocławiu, Technologia, 1982, 199, 151-166.

Bogoczek R., Kociołek-Balawejder E., Badanie właściwości styrenowo-diwinylobenze-nowych jonitów metylenotiolowych, „Polimery”, 1985, 30, 439-445.

Bogoczek R., Wolak P., Krzemoorganiczne wymieniacze jonowe, „Przemysł Chemiczny”, 1985, 64, 518-521.

Bogoczek R., Kociołek-Balawejder E., Kationit tiofenolowy otrzymany z makroporowatego, sulfonowego kationitu styrenowo-diwinylobenzenowego, „Chemia Stosowana”, 1986, 30, 591-602.

Bogoczek R., Kociołek-Balawejder E., N-monohalogeno- and N,N-dihalogeno- poly/styrene-co-divinylbenzene/sulphonamides, „Polymer Communications”, 1986, 27, 286-288.

Bogoczek R., Kociołek-Balawejder E., Synthesis and main properties of uniformly chlorosulfonyl-substituted styrene-diwinylbenzene resins, "Reactive Polymers", 1986, 4, 311-316.

Bogoczek R., Kociołek-Balawejder E., Właściwości specyficznego dla jonów rtęciowych kationitu Imac TMR, „Przemysł Chemiczny”, 1986, 65, 368-371.

Bogoczek R., Surowiec J., Chemical modification of styrene-divinylbenzene copolymers by dialkyl phosphates, "Polymer", 1986, 27, 631-634.

Bogoczek R., Kociołek-Balawejder E., Infrared spectra of uniformly chlorosulfonyl-substituted styrene-divinylbenzene resins, "Reactive Polymers", 1987, 7, 57-62.

Bogoczek R., Kociołek-Balawejder E., Kationity s chlorirujuscimi, okisitielnymi i baktericidnymi svoistvami, Vysokomolekuljarnyje soedinenija, 1987, 29(A), 2346-2352.

Bogoczek R., Kociołek-Balawejder E., Pochodna chlorosulfonylowa kopolimeru styren/diwinylobenzen - interesujacy pótprodukt do syntezy sorbentów specjalnych, „Polimery”, 1987, 32, 393-397.

Bogoczek R., Kociołek-Balawejder E., Próby syntezy kationitu o sulfonowych grupach funkcyjnych, Prace Naukowe Akademii Ekonomicznej we Wrocławiu, Technologia, 1987, 398, 59-69.

Bogoczek R., Kociołek-Balawejder E., Sintez i svojstva sopolimerov stirola i divinilbenzola sodierżascich N-monoiodsulfonamidnye gruppy, Vysokomolekuljarnye soedinenija, 1987, 29(B), 643-645.

Bogoczek R., Kociołek-Balawejder E., Synteza kationitu sulfinowego z makroporowatego sulfonowego kationitu styreno-diwinylonenzenowego, „Polimery”, 1987, 32, 12-15.

Bogoczek R., Pińkowska H., Surowiec J., Badania nad zastosowaniem różnych procesów jonitowych do rozdziału składników technologicznego roztworu rodanku sodu, Prace Naukowe Akademii Ekonomicznej we Wrocławiu, Technologia, 1987, 398, 71-83.

Bogoczek R., Surowiec J., Superacid systems on solid carriers, "Chemie Ingenieur Technik", 1987, 59, 178-179.

Bogoczek R., Kociołek-Balawejder E., Chemicznie aktywne kopolimery styreno-diwinylo-benzenowe o siarkowych grupach funkcyjnych, „Chemik”, 1988, 41, 10-16.

Bogoczek R., Kociołek-Balawejder E., Thermal analysis of macromolecular Haloamines, "Journal of Thermal Analysis", 1988, 33, 1109-1117. 
Bogoczek R., Surowiec J., Thermal analysis of 1-hydroxiethylidenediphosphonic acid and its salts, "Journal of Thermal Analysis", 1988, 33, 1103-1108.

Surowiec J., Bogoczek R., Studies on the thermal stability of the perfluorinated cation-exchange membrane Nafion-417, "Journal of Thermal Analysis", 1988, 33, 1097-1102.

Bogoczek R., Kociołek-Balawejder E., Analiza siarkowych grup funkcyjnych w chemicznie aktywnych kopolimerach styreno-diwinylobenzenowych, Prace Naukowe Akademii Ekonomicznej we Wrocławiu, Technologia, 1989, 476, 111-212.

Bogoczek R., Kociołek-Balawejder E., Studies on a Macromolecular Dichloroamine - the N,N-Dichloro poly (Styrene-co-Divinylbenzene) Sulfonamide, "Die Angewandte Macromoleculare Chemie", 1989, 169, 119-135.

Bogoczek R., Kociołek-Balawejder E., Właściwości kationitu sulfinowego otrzymanego z kopolimeru styren/diwinylobenzen, „Polimery”, 1989, 34, 398-402.

Bogoczek R., Kociołek-Balawejder E., Kogut A., Usuwanie jonów rtęci ze ścieków, „Przemysł Chemiczny", 1989, 68, 83-85.

Bogoczek R., Kociołek-Balawejder E., N-Bromo-poly(styrene-co-divinyl-benzene) sulfonamide metal salts, „Die Angewandte Makromoleculare Chemie”, 1991, 188, 85-96.

Bogoczek R., Wolak P., Synteza i badanie właściwości sulfonowego kationitu polifenylosiloksanowego, Prace Naukowe Akademii Ekonomicznej we Wrocławiu, Technologia, 1991, 605, 45-58.

Bogoczek R., Pińkowska H., Modyfikacja chemiczna kopolimerów kwasu akrylowego i diwinylobenzenu typu Wofatit. Synteza chlorokarbonylowych pochodnych, Prace Naukowe Akademii we Wrocławiu, Technologia, 1992, 626, 81-91.

Bogoczek R., Wolak P., Badania nad synteza i modyfikacja chemiczna poli(3-chloropropylosiloksanu), Prace Naukowe Akademii Ekonomicznej we Wrocławiu, Technologia, 1992, 626, 93-108.

Bogoczek R., Kociołek-Balawejder E., Synthesis and basic characterization of a macromolecular dibromoamine: N,N-dibromo-poly(styrene-co-divinyl-benzene) sulfonamide, "Polymer", 1993, 34, 2883-2888.

Bogoczek R., Leja J., Zastosowanie HPLC do wykrywania niektórych związów zawartych w technicznym kwasie 2-hydroksypropionowym, Prace Naukowe Akademii Ekonomicznej we Wrocławiu, Technologia, 1994, 675, 35-44.

Bogoczek R., Wolak P., Badanie właściwości chemicznych poli(3-merkaptopropylo-siloksanu), Prace Naukowe Akademii Ekonomicznej we Wrocławiu, Technologia, 1994, 675, 53-62.

Bogoczek R., Wolak P., Sulfhydrylowy krzemoorganiczny kationit o podwyższonej aktywności i stabilności termicznej, Prace Naukowe Akademii Ekonomicznej we Wrocławiu, Technologia, 1994, $675,45-52$.

Bogoczek R., Kwas mlekowy i pochodne, własności fizyczne i chemiczne, [w:] Zastosowanie kwasu mlekowego i jego pochodnych, Wydawnictwo Polskiego Towarzystwa Technologów Żywności Oddział Wielkopolski, Poznań 1995, 35-57.

Bogoczek R., Kociołek-Balawejder E., Willmann-Cholewińska M., Disinfecting properties of N-halogeno- and $N, N$-dihalogenosulfonamide resins being in contact with natural river water, "Polish Journal of Applied Chemistry", 1995, 39, 451-458.

Bogoczek R., Leja J., Pińkowska H., Oznaczanie kwasów karboksylowych za pomoca HPLC, Prace Naukowe Akademii Ekonomicznej we Wrocławiu nr 728, Technologia, 1996, 1, 165-179.

Bogoczek R., Leja J., Pińkowska H., Oznaczanie sacharydów za pomoca HPLC, Prace Naukowe Akademii Ekonomicznej we Wrocławiu nr 728, Technologia, 1996, 1, 153-165.

Bogoczek R., Pińkowska H., Surowiec J., New ion exchange techniques of sodium thiocyanate recovery from HCN-postutilization solutions, "Polish Journal of Applied Chemistry", 1996, 40, 263-272.

Bogoczek R., Napierała W., Kwas mlekowy - jakość, właściwości i kierunki zastosowań, „Przemysł Spożywczy", 1998, 6, 43-47.

Bogoczek R., Pińkowska H., Covalent reactions on carboxylic cation exchangers poly(acrylic acid - dv / esters), "Reactive \& Functional Polymers", 2003, 54, 117-130. 
Bogoczek R., W drodze od technologii tradycyjnej do technologii przyjaznej środowisku, Prace Naukowe Akademii Ekonomicznej we Wrocławiu, Zielona Chemia, 2004, 1041, 15-23.

Zahorodna M., Bogoczek R., Gtębokie utlenianie sulfonowanej żywicy styrenowo-diwinylobenzenowej w obecności odczynnika Fentona - identyfikacja składu chemicznego produktu, Prace Naukowe Akademii Ekonomicznej we Wrocławiu, Zielona Chemia, 2004, 1041, 206-1215.

Bogoczek R., Nauczanie technologii chemicznej na interdyscyplinarnym Wydziale Inżynieryjno-Ekonomicznym, Akademii Ekonomicznej we Wrocławiu, „Chemik”, 2005, 58, 29-30.

Bogoczek R., Kociołek-Balawejder E., Stanisławska E., Macromolecular N-chloro-sulfonamide as an oxidant for residual nitrites in aqueous media, "Industrial \& Engineering Chemistry Research", 2005, 44, 8530-8534.

Bogoczek R., Zahorodna M., Kierunki zagospodarowania zużytych jonitów, Monografie Komitetu Inżynierii Środowiska PAN, 2005, 32, 1043-1051.

Bogoczek R., Kociołek-Balawejder E., Stanisławska E., A macromolecular oxidant, the N,N-dichlorosulfonamide for removal of residual nitrites from aqueous media, "Reactive \& Functional Polymers", 2006, 66, 609-617.

Pińkowska H., Bogoczek R., Zastosowanie płynów w stanie nadkrytycznym do recyklingu surowcowego materiałów polimerowych, „Przemysł Chemiczny”, 2006, 85, 894-897.

Bogoczek R., Zrównoważony rozwój w technologii chemicznej na świecie, Prace Naukowe Akademii Ekonomicznej we Wrocławiu, 2007, 1190, 211-223.

Bogoczek R., Kociołek-Balawejder E., Stanisławska E., Żabska A., Oxidation of Fe(II) to Fe(III) by heterogeneous oxidant as a convenient process for iron removal from water, [w:] Environmental Engineering, ed. L. Pawłowski, M. Dudzińska, A. Pawłowski, Taylor \& Francis, London 2007, 183-190.

Bogoczek R., Kociołek-Balawejder E., Stanisławska E., Żabska A., Using macroporous N-chlorosulfonamide S/DVB copolymer as an aid to iron removal from water, "Pure and Applied Chemistry", 2007, 79, 1491-1503.

Bogoczek R., Kociołek-Balawejder R., Stanisławska E., Examination of the reaction of a macromolecular sulfonamide with sodium nitrite in acidic media, "Polimery", 2007, 52, 137-141.

Bogoczek R., Molenda A., Nadtlenek wodoru i jego addukty ze zwiazkami małocząsteczkowymi, „Przemysł Chemiczny", 2007, 86, 24-28.

Bogoczek R., Molenda A., Nadtlenek wodoru i jego addukty ze związkami wielkoczasteczkowymi, „Przemysł Chemiczny”, 2007, 86, 111-113.

Zahorodna M., Bogoczek R., Oliveros E., Braun A.M., Application of the Fenton process to the dissolution snd mineralization of ion exchange resins, "Catalysis Today", 2007, 129, 200-206.

Zahorodna M., Bogoczek R., Oliveros E., Braun A.M., Partial oxidation of ion exchange resins by the Fenton process for recycling purposes, "Recents Progress en Genie des Procedes", 2007, 94, 1-8.

Bogoczek R., Kociołek-Balawejder E., Stanisławska E., Potentiometric studies of oxidation-reduction reactions with redox copolymers, "Journal of Applied Polymer Science", 2008, 107, 2190-2195.

Zahorodna M., Oliveros E., Worner M., Bogoczek R., Braun A.M., Dissolution and mineralization of ion exchange resins: Differentiation between heterogeneous and homogeneous (photo)-Fenton processes, "Photochemical \& Photobiological Sciences", 2008, 7, 1480-1492.

\section{Patenty}

Bogoczek R., Sposób otrzymywania żywicy aniono- $i$ elektronowymiennej posiadającej ponadto własności retardacyjne, Pat. pol. 87033, $1976 \mathrm{r}$.

Bogoczek R., Łazęcki S. i inni, Sposób oczyszczania roztworów siarczanu glinu, Pat. pol. 81929, 1977 r. Bogoczek R., Wasilewski J. i inni, Sposób wytwarzania kwasu szczawiowego i saletry sodowej, Pat. pol. $105839,1980 \mathrm{r}$. 
Bogoczek R., Sposób rozdzielania melasu, Pat. pol. 116438, 1982 r.

Bogoczek R., Wasilewski J. i inni, Sposób wytwarzania kwasu szczawiowego ze szczawianu dwusodowego, Pat. pol. 116005, $1983 \mathrm{r}$.

Bogoczek R., Surowiec J. i inni, Sposób wytwarzania kwasu hydroksyetylidenodwufosfonowego, Pat. pol. $117685,1983 \mathrm{r}$.

Bogoczek R., Surowiec J., Sposób otrzymywania nowych selektywnych kationitów zawierających fosfor, Pat. pol. 120464, 1983 r.

Bogoczek R., Surowiec J., Sposób wytwarzania kwasu 3,5-dwuchloro-4-hydroksybenzoesowego, Pat. pol. 125642, $1984 \mathrm{r}$.

Bogoczek R., Kociołek-Balawejder E., Miemus G., Waniczek H., Sposób wytwarzania aldehydu 3,4,5-trójmetoksybenzoesowego, Pat. pol. 126462, 1984 r.

Bogoczek R., Kociołek-Balawejder E., Sposób otrzymywania nowych chlorosulfonowych sorbentów styrenowo-dwuwinylobenzenowych, Pat. pol. 132284, $1986 \mathrm{r}$.

Bogoczek R., Kociołek-Balawejder E., Sposób otrzymywania organicznych wymieniaczy jonowych zawierajacych sulfinianowe grupy funkcyjne, Pat. pol. 133304, $1986 \mathrm{r}$.

Bogoczek R., Surowiec J., Sposób wytwarzania kwasu 3,4,5-trójhydroksybenzoesowego poprzez hydrolizę kwasu 3,5-dwubromo-4-hydroksybenzoesowego, Pat. pol. 133307, 1986 r.

Bogoczek R., Surowiec J., Sposób wytwarzania kwasu 3,5-dwubromo-4-hydroksybenzoesowego, Pat. pol. 133327, $1986 \mathrm{r}$.

Bogoczek R., Kociołek-Balawejder E., Sposób wytwarzania czystego kwasu 2,4-dwunitrobenzoesowego, Pat. pol. 133328, 1986 r.

Bogoczek R., Surowiec J., Sposób wytwarzania kwasu galusowego poprzez hydrolizę kwasu 3,5-dwujodo-4-hydroksybenzoesowego, Pat. pol. 134213, $1986 \mathrm{r}$.

Bogoczek R., Surowiec J., Sposób wytwarzania kwasu 3,5-dwujodo-4-hydroksybenzoesowego, Pat. pol. 134213, $1986 \mathrm{r}$.

Bogoczek R., Surowiec J., Sposób wydzielania kwasu galusowego z produktu hydrolizy kwasów 3,5-dwuhalogeno-4-hydroksybenzoesowego, Pat. pol. 136156, $1986 \mathrm{r}$.

Bogoczek R., Surowiec J., Sposób rozdziału produktów hydrolizy kwasu 3,5-dwuchloro-4-hydroksybenzoesowego, Pat. pol. 136158, $1986 \mathrm{r}$.

Bogoczek R., Surowiec J., Sposób przemiany kwasu 3,5-dwuchloro-4-hydroksybenzoesowego na pirogalol i jego pochodne karboksylowe, Pat. pol. 137124, $1987 \mathrm{r}$.

Bogoczek R., Kociołek-Balawejder E., Sposób dezynfekcji wody i wodnych roztworów technologicznych, Pat. pol. 137914, 1987 r.

Bogoczek R., Kociołek-Balawejder E., Sposób otrzymywania nowych ufunkcyjnionych kopolimerów styrenowo-diwinylobenzenowych, Pat. pol. 138767, $1987 \mathrm{r}$.

Bogoczek R., Kociołek-Balawejder E., Sposób otrzymywania nowej żywicy o szkielecie styrenowo-diwinylobenzenowym, Pat. pol. 138768, $1987 \mathrm{r}$.

Bogoczek R., Kociołek-Balawejder E., Sposób otrzymywania nowej żywicy jonowymiennej o szkielecie styrenowo-diwinylobenzenowym, Pat. pol. 138970, $1987 \mathrm{r}$.

Bogoczek R., Kociołek-Balawejder E., Sposób otrzymywania nowej, ufunkcyjnionej żywicy styrenowo-diwinylobenzenowej, Pat. pol. 138988, $1987 \mathrm{r}$.

Bogoczek R., Kociołek-Balawejder E., Sposób otrzymywania uaktywnionych żywic sulfomonochloramidowych $i$ sulfodichloramidowych o szkielecie styrenowo-diwinylobenzenowym, Pat. pol. $138989,1987 \mathrm{r}$.

Bogoczek R., Kociołek-Balawejder E., Sposób otrzymywania nowych ufunkcyjnionych żywic o szkielecie styrenowo-diwinylobenzenowym, Pat. pol. 138990, $1987 \mathrm{r}$.

Bogoczek R., Kociołek-Balawejder E., Sposób unieszkodliwiania ścieków rodankowych, Pat. pol. $151268,1989 \mathrm{r}$.

Bogoczek R., Surowiec J. i inni, Sposób wytwarzania rodanku sodowego specjalnie czystego i siarczanu sodowego, Pat. pol. 150396, 1990 r. 
Bogoczek R., Surowiec J. i inni, Sposób wytwarzania rodanku sodowego, Pat. pol. 150397, 1990 r.

Bogoczek R., Surowiec J. i inni, Sposób wytwarzania rodanku sodowego specjalnie czystego i siarczanu żelazowego, Pat. pol. 150398, $1990 \mathrm{r}$.

Bogoczek R., Kociołek-Balawejder E., Sposób unieszkodliwiania ścieków cyjankowych, Pat. pol. $151267,1990 \mathrm{r}$.

Bogoczek R., Kociołek-Balawejder E., Sposób usuwania odczynu utleniającego z roztworów, Pat. pol. $152829,1991 \mathrm{r}$.

Bogoczek R., Pińkowska H. i inni, Sposób otrzymywania tiocyjanianu sodowego, Pat. pol. 152877, $1991 \mathrm{r}$.

Bogoczek R., Surowiec J., Krawczyk J., Sposób otrzymywania czystego rodanku sodowego, Pat. pol. $152878,1991 \mathrm{r}$.

\section{Rozprawy doktorskie}

Paweł Nowak, Studia nad wytwarzaniem kwasu szczawiowego z soli kwasu szczawiowego, 3.11.1977 r.

Julia Tomaszewska, Studia nad dezaktywacja katalizatora do niskociśnieniowej syntezy metanolu, 15.12.1978 r.

Andrzej Żychiewicz, Utlenianie siarkowodoru za pomoca powietrza z użyciem żelazowo-karboksylowych wymieniaczy jonowych jako katalizatorów, 23.02.1978 r.

Joanna Surowiec, Synteza i badanie własności kationitów fosfonowych otrzymanych z kopolimerów Wofatit, 27.03.1980 r.

Elżbieta Kociołek-Balawejder, Synteza, badanie i modyfikacja kationitów polistyrenodiwinylobenzenowych zawierajacych siarke w grupie funkcyjnej, 12.06.1986 r.

Paweł Wolak, Synteza i badanie właściwości krzemoorganicznych wymieniaczy jonowych, $2.06 .1989 \mathrm{r}$.

Hanna Pińkowska, Modyfikacja chemiczna kopolimerów kwasu akrylowego i diwinylobenzenu, 10.10.1994 r.

Monika Zahorodna, Optymalizacja utleniajacej degradacji sulfonowych kationitów z wykorzystaniem procesów Fentona i foto-Fentona, 04.04.2008 r.

\section{Podręczniki i skrypty}

Bogoczek R., Surowiec J., Podstawy technologii chemicznej, Wydawnictwo Akademii Ekonomicznej we Wrocławiu, Wrocław 1988.

Bogoczek R., Surowiec J., Technologia chemiczna nieorganiczna, Wydawnictwo Akademii Ekonomicznej we Wrocławiu, Wrocław 1989.

Bogoczek R. (red.), Materiały pomocnicze do ćwiczeń i wykładów z technologii chemicznej organicznej, Wydawnictwo Uczelniane Akademii Ekonomicznej we Wrocławiu, Wrocław 1989.

Bogoczek R. (red.), Materiaty pomocnicze do ćwiczeń i wykladów z technologii nieorganicznej, Wydawnictwo Uczelniane Akademii Ekonomicznej we Wrocławiu, Wrocław 1989.

Bogoczek R., Kociołek-Balawejder E., Technologia chemiczna organiczna, część 1, Wydawnictwo Akademii Ekonomicznej we Wrocławiu, Wrocław 1990.

Bogoczek R., Kociołek-Balawejder E., Technologia chemiczna organiczna, surowce i pólprodukty, Wydawnictwo Akademii Ekonomicznej we Wrocławiu, Wrocław 1992. 